\title{
Severe Pulmonary Hypertension in Chronic Idiopathic Myelofibrosis
}

\author{
M. Halank ${ }^{\mathrm{a}}$ \\ C. $\operatorname{Marx}^{\mathrm{a}}$ \\ G. Baretton ${ }^{b}$ \\ K.-M. Müller ${ }^{c}$ \\ G. Ehninger ${ }^{a}$ \\ G. Höffken ${ }^{a}$ \\ a Medizinische Klinik I,

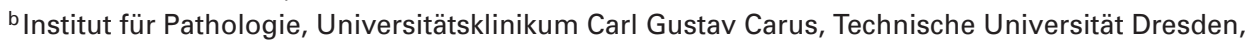 \\ c Institut für Pathologie, Berufsgenossenschaftliche Kliniken Bergmannsheil, Ruhr-Universität Bochum, Deutschland
}

\section{Key Words}

Myeloproliferative disorders, chronic - Myelofibrosis, chronic idiopathic $\cdot$ Pulmonary hypertension

\section{Summary}

Background: Chronic myeloproliferative disorders (CMPD) seem to be associated with an increased risk for pulmonary hypertension (PH). Case Report: A patient with history of chronic idiopathic myelofibrosis (CIMF) presented with progressive dyspnea (New York Heart Association class III). Until this time he had not received specific treatment for CIMF. Echocardiography and rightheart catheterization confirmed $\mathrm{PH}$. Further diagnostic procedures excluded a specific cause of $\mathrm{PH}$. Therefore, primary $\mathrm{PH}$ was assumed. 2 years later he presented again with progressive dyspnea due to a progress of $\mathrm{PH}$. A few days later the patient died from acute posterior myocardial infarction. Pathologic examination of the lung showed an obstruction of the small vessels by conglomerates of megakaryocytes. Discussion: We conclude that PH developed secondarily due to CMPD. PH should be suspected in patients with CMPD and should influence the decision for treatment of CMPD.

\section{Introduction}

The classification of pulmonary hypertension ( $\mathrm{PH})$ according to the World Health Organization (WHO) 1998 has led to a

\section{Schlüsselwörter}

Myeloproliferative Erkrankungen, chronisch · Myelofibrose, chronisch idiopathische - Pulmonale Hypertonie

\section{Zusammenfassung}

Hintergrund: Chronische myeloproliferative Erkrankungen (CMPD) scheinen mit einem erhöhten Risiko für pulmonale Hypertonie (PH) assoziiert zu sein. Kasuistik: Ein Patient mit chronisch idiopathischer Myelofibrose (CIMF) wurde aufgrund einer progressiven Belastungsdyspnoe (New York Heart Association Stadium III) überwiesen. Bis zu diesem Zeitpunkt erhielt er keine spezifische Behandlung seiner CIMF. Echokardiographie und Rechtsherzkatheter ergaben das Vorliegen einer $\mathrm{PH}$. Eine spezifische Ursache der $\mathrm{PH}$ konnte zunächst ausgeschlossen werden. Somit wurde das Vorliegen einer primären $\mathrm{PH}$ vermutet. 2 Jahre später wurde der Patient mit erneut verschlechterter Belastungsdyspnoe vorgestellt, wobei ein Progress der $\mathrm{PH}$ feststellbar war. Einige Tage später verstarb der Patient an einem Hinterwandinfarkt. Die Autopsie des Lungengewebes zeigte einen Verschluss der kleinen Lungengefäße durch Konglomerate von Megakaryozyten. Diskussion: Die Entwicklung der $\mathrm{PH}$ ist bei diesem Patienten als Folge der CMPD einzuschätzen. Das Vorliegen einer PH bei Patienten mit CMPD sollte die Entscheidung zu spezifischen therapeutischen Maßnahmen hinsichtlich der CMPD beeinflussen.

descriptive classification of pulmonary hypertension consisting of 5 groups, among them one summarizing miscellaneous diseases [1]. Several recent case reports and smaller studies suggest an association of chronic myeloproliferative disorders

\begin{tabular}{|c|c|c|}
\hline KARGER & (C) 2004 S. Karger GmbH, Freiburg & $\begin{array}{l}\text { Dr. med. Michael Halank } \\
\text { Medizinische Klinik und Poliklinik } 1\end{array}$ \\
\hline $\begin{array}{l}\text { Fax +49 } 7614520714 \\
\text { E-mail Information@Karger.de } \\
\text { www.karger.com }\end{array}$ & $\begin{array}{l}\text { Accessible online at: } \\
\text { www.karger.com/onk }\end{array}$ & $\begin{array}{l}\text { Universitätsklinikum Carl Gustav Carus der TU Dresden } \\
\text { Fetscherstr. 74, D-01307 Dresden } \\
\text { Tel. +49 } 351 \text { 458 3417, Fax -5701 } \\
\text { E-mail Michael.Halank@uniklinikum-dresden.de }\end{array}$ \\
\hline
\end{tabular}


such as polycythemia vera, essential thrombocythemia, or chronic idiopathic myelofibrosis, and severe pulmonary hypertension [2-6]. In these cases, post-mortem examination of the lungs typically reveals intima proliferates and capillary occlusion by megakaryocytes as well as extramedullary hematopoiesis [6]. Likewise, an association of myelodysplastic syndrome or chronic myeloid leukemia and pulmonary hypertension was reported [5].

Here, we report on a patient who developed severe pulmonary hypertension due to chronic idiopathic myelofibrosis.

\section{Case Report}

In a 61-year-old male patient chronic idiopathic myelofibrosis (CIMF) was diagnosed. At this time, he suffered from constitutional weakness and diffuse pain in muscles and joints. Hepatosplenomegaly was detectable only by abdominal ultrasound. The peripheral blood showed mild anemia (7 mmol/l; normal range: $8.6-12.1 \mathrm{mmol} / \mathrm{l}$ ) and a leukoerythroblastosis with nucleated red blood cells, granulocyte precursors and tear-dropshaped erythrocytes. Fluorescence in-situ hybridisation for the $b c r-a b l$ fusion gene was negative. Aspiration of bone marrow was not successful. Bone marrow biopsy revealed a prefibrotic stage of CIMF with increased megakaryopoiesis and granulopoiesis with typical abnormalities in maturation of both cell lines. Megakaryocytes showed characteristic 'cloudlike' and 'balloon-shaped' nuclei and clustering. Erythropoiesis was decreased and iron staining was positive in bone marrow macrophages. Thus, a diagnosis of other myeloproliferative diseases (e.g. polycythemia vera or essential thrombocythemia) could be ruled out by histopathologic and hematologic findings.

One year after CIMF was diagnosed, the patient was referred to our hospital for the first time due to progressive dyspnea (New York Heart Association class III) and intermittent depending edema. Furthermore, he had a history of arterial hypertension and atrial fibrillation with consecutive calcium-channel-blocker and phenprocoumon therapy. The patient had never smoked in his life. Physical examination revealed a tachypnoeic patient, hepatosplenomegaly and dependent edema. Analysis of blood gases showed a mild respiratory partial insufficiency and chest-radiographic signs of pulmonary hypertension. Echokardiography confirmed a rightventricular endsystolic pressure (RVESP) of $65 \mathrm{mmHg}$ and dilatation of the right ventricle. Subsequently, right-heart catheterization was performed and a cardiac index of $2.6 \mathrm{l} / \mathrm{min} / \mathrm{m}^{2}$, a mean pulmonary arterial pressure of $33 \mathrm{mmHg}$, a pulmonary vascular resistance of $430 \mathrm{dyn} * \mathrm{~s}^{*} \mathrm{~cm}^{-5}$, a pulmonary vascular occlusion pressure of $10 \mathrm{mmHg}$, and a mixed venous oxygen saturation of $57 \%$ was found. The walking distance within 6 minutes was $320 \mathrm{~m}$.

Bodyplethysmography showed normal ventilatory parameters. Carbon monoxide diffusion was normal. High-resolution computed tomography of the chest revealed no significant signs of interstitial lung disease. A ventilation/perfusion scintigraphic scan revealed no signs of pulmonary embolism. Abdominal sonography showed hepatosplenomegaly. Laboratory investigations revealed mild anemia, no signs of hemolysis, elevation of creatinine and urea, non-selective proteinuria, slight elevation of rheuma factors and blood sedimentation. Antinuclear antibodies were normal. Renal biopsy revealed signs of focal segmental mesangioproliferative glomerulonephritis of non-IgA type. According to these investigations, primary pulmonary hypertension was assumed. Therapy with phenprocoumon and low-dose calcium antagonists was continued. Bosentan and prostanoids were not given because these substances were lacking approval for the therapy of PAH in Germany at this time. Steroid treatment was started which improved proteinuria but led to steroid-induced diabetes mellitus. After discharge from hospital radiation of the spleen was

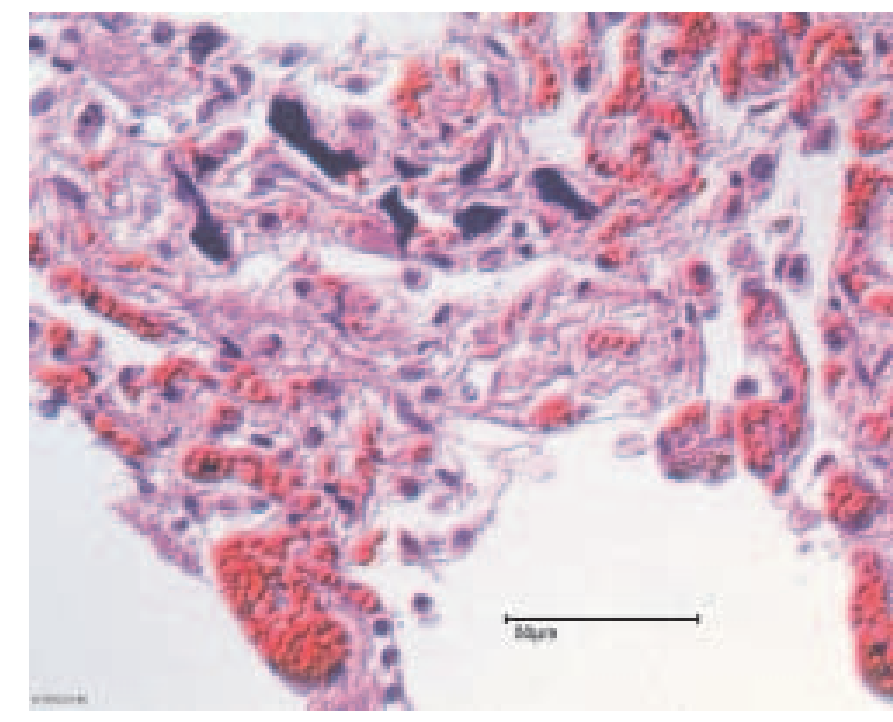

Fig. 1. Pulmonary manifestation of chronic idiopathic myelofibrosis (CIMF) in a patient with PAH: Ectatic and hyperemic precapillary lung vessels with bizarre-shaped embolizing megakaryocytes (staining against hematoxylin/ eosine).

performed after initiation of a therapy with hydroxurea due to excessive hepatosplenomegaly.

Two years after the first presentation, the patient was admitted again with progedient dyspnea, febrile temperature and lumbal pain which had continued for 3 weeks. His general condition was reduced, signs of cardiac decompensation were not found. Laboratory investigation revealed slight anemia (hemoglobin $7.2 \mathrm{mmol} / \mathrm{l}$ ), slightly elevated leukocytes (10.5 Gpt/l, normal range: 3.8-9.8 Gpt/l), C-reactive protein of $180 \mathrm{mg} / \mathrm{l}$ (normal: <5 $\mathrm{mg} / \mathrm{l}$ ), and creatinine levels of $165 \mu \mathrm{mol} / \mathrm{l}$ (normal: $<115 \mu \mathrm{mol} / \mathrm{l}$ ). Lactate dehydrogenase was increased $(47 \mu \mathrm{mol} / \mathrm{s} * 1$, normal range: $2.25-3.75$ $\mu \mathrm{mol} / \mathrm{s} * \mathrm{l})$. During the course of disease, platelet counts ranged between 500 and $800 \mathrm{Gpt} / \mathrm{l}$ (normal range: 150-400 Gpt/l). Cardiac enzymes were normal and the ECG showed no signs of ischemia. Urine analysis, radiographic and computed tomographic examinations of chest and spine as well as bone scintigraphic scans showed no foci of infection. Transesophageal echocardiography revealed no signs of endocarditis but a progressive elevation of the RVESP $(85 \mathrm{mmHg}$ ) with normal left-ventricular function. Left atrial blood flow was reduced and a spontaneous echocardiographic contrast without formation of thrombotic material was seen. Sonographically, a progress of hepatosplenomegaly was found. Under therapy with phenprocoumon, the International Normalized Ratio (INR) was within therapeutic range. After initiation of antibiotic therapy, the levels of C-reactive protein decreased. Bone marrow biopsy and rightheart catheterization were scheduled.

A few days after admission, the patient collapsed unobserved and was found dead in the restroom. On autopsy, acute myocardial infarction of the right coronary artery was found as cause of death. Chronic idiopathic myelofibrosis with massive hepatosplenomegaly and signs of extramedullary hematopoesis was confirmed. In the autopsy material an initial patchy reticulin fibrosis of the bone marrow was detectable; a diffuse fibrosis, however, was not present; the number of CD34-positive blasts was not increased. The pulmonary arteries were sclerotic, the right ventricle was hypertrophic and dilated. Examination of the lungs revealed ectatic small vessels with intima proliferates and capillary occlusion by megakaryocytes (fig. 1). The size and shape of the nuclei of these megakaryocytes matched the bizarre, 'cloud-like' nuclei of the megakaryocytes in the bone marrow and extramedullary hematopoesis. 


\section{Discussion}

The groups of pulmonary hypertension $(\mathrm{PH})$ according to the definition of the WHO in Evian 1998 consist of pulmonary arterial hypertension (PAH), pulmonary venous hypertension, pulmonary hypertension associated with disorders of the respiratory system and/or hypoxemia, pulmonary hypertension caused by chronic thromboembolic disease, and pulmonary hypertension associated with miscellaneous diseases [1]. The group of PAH consists of patients with primary pulmonary hypertension and patients with PAH related to collagenous vascular disease, congenital systemic-pulmonary shunts, portal hypertension, HIV infection and PAH related to drugs and toxins. A therapy with prostacyclin, its derivates or with endothelin-receptor antagonists is recommended for these patients. The Third World Symposium on Pulmonary Arterial Hypertension in Venice (June 2003), proposed to rank patients with $\mathrm{PAH}$ related to myeloproliferative disorders among the group of PAH [11].

Tumor microembolism leading to PH may be associated with various tumors [7] and also other systemic diseases such as amyloidosis may present as $\mathrm{PH}[8]$. In patients with progressive myeloproliferative syndrome, megakaryocyte embolism of pulmonary vessels may be caused by translocation of megakaryocytes from the bone marrow, spleen or liver to the lungs, finally leading to $\mathrm{PH}$ [6]. In our patient, $\mathrm{PH}$ could be explained by predominance of ectatic small vessels with intima proliferates and massive pulmonary capillary occlusion by megakaryocytes. Unfortunately, the proper diagnosis was only found post mortem, as also reported previously by Yao et al. [9]. This case outlines important implications for clinical practice. Firstly, it demonstrates that PH may be caused directly by CMPD and should be taken into consideration as a differential diagnosis when a patient suffers from progressive chronic dyspnea. Secondly, the rising numbers of reports on pulmonary hypertension due to various diseases such as hematologic disorders raise the question for an earlier invasive diagnostic approach in these patients using transbronchial biopsy or minimally invasive open lung biopsy.

Early diagnostic clarification of the etiology of PH is necessary since it might influence the decision for therapy of the underlying hematologic disorder as well as the early treatment of $\mathrm{PH}$ itself. This is important since it was shown recently that patients with $\mathrm{PH}$ and myelofibrosis might benefit from lowdose, whole-lung radiotherapy [10].

\section{References}

1 British Cardiac Society Guidelines and Medical Practice Committee: Recommendations on the management of pulmonary hypertension in clinical practice. Heart 2001;86(Suppl I):i1-i13.

2 Marvin KS, Spellberg RD: Pulmonary hypertension secondary to thrombocytosis in a patient with myeloid metaplasia. Chest 1993;103:622-644.

3 Nand S, Orfei E: Pulmonary hypertension in polycythemia vera. Am J Hematol 1994;47:242-244.

4 Garcia-Manero G, Schuster SJ, Patrick H, Martinez $\mathrm{J}$ : Pulmonary hypertension in patients with myelofibrosis secondary to myeloproliferative diseases. Am J Hematol 1999;60:130-135.
5 Dingli D, Utz JP, Krowka MJ, Oberg AL, Tefferi A: Unexplained pulmonary hypertension in chronic myeloid disorders. Chest 2001;120:801-808

6 Kuhnen C, Cupisti A, Bosse A, Müller KM: Die Bedeutung pulmonaler Megakaryozyten bei myeloproliferativen Systemerkrankungen. Atemw Lungenkrkh 1995;21:360-361.

7 Hibbert M, Braude S: Tumour microembolism presenting as 'primary pulmonary hypertension'. Tho$\operatorname{rax}$ 1997;52:1016-1017.

8 Dingli D, Utz JP, Gertz MA: Pulmonary hypertension in patients with amyloidosis. Chest 2001;120: 1735-1738.
9 Yao DX, Flieder DB, Hoda SA: Pulmonary tumor thrombotic microangiopathy: An often missed antemortem diagnosis. Arch Pathol Lab Med 2001; 125:304-305.

10 Steensma DP, Hook CC, Stafford SL, Tefferi A: Low-dose, single-fraction, whole-lung radiotherapy for pulmonary hypertension associated with myelofibrosis with myeloid metaplasia. Brit J Haematol 2002;118:813-816.

11 Simoneau G, Galie N, Rubin LJ, Langleben D, Seeger W, Domenighetti G, Gibbs S, Lebrec DS, Speich R, Beghetti M, Rich S, Fishman A: Clinical classification of pulmonary hypertension. J Am Coll Cardiol 2004;43:5S-12S. 